DOI: https://doi.org/10.35961/jppmkepri.v1i2.184

\title{
Implementasi Program Kuliah Kerja Nyata Dari Rumah Pada Masyarakat Kelurahan Air Raja Kota Tanjungpinang
}

\author{
Kamaruzaman $^{1 *}$, Syahrul Ulum ${ }^{2}$, Susi Susilawati ${ }^{3}$, Latifa Hanum Ghultom ${ }^{4}$, Ainul Mutaqhoro ${ }^{5}$, \\ Linda Sari ${ }^{6}$, Egi Iskarisma ${ }^{7}$, Maulana Aqlis Azet ${ }^{8}$, M. Sufyan Nur Zuhaili ${ }^{9}$, Zahari ${ }^{10 .}$ \\ ${ }^{1}$ STAIN Sultan Abdurrahman Kepulauan Riau, Bintan, Kepulauan Riau, 29123, Indonesia \\ *kamaruzaman@stainkepri.ac.id
}

\begin{abstract}
Abstrak
Di masa pendemi Covid-19, berbagai aktifitas mulai dari bekerja, belajar, beribadah, hingga bersosialisasi dianjurkan dilakukan dari rumah sebagai upaya pencegahan penyebaran virus. Kegiatan KKN di Era Pandemi Covid-19 Kelompok Biru STAIN Sultan Abdurrahman Kepulauan Riau juga dilakukan berbasis pengembangan program dari rumah atau dikenal dengan istilah KKN-DR (kuliah kerja nyata dari rumah). Dengan demikian kewajiban kuliah dan upaya pencegahan penyebaran Covid-19 sama-sama dapat terlaksana. Kegiatan pengabdian dan pemberdayaan masyarakat dilaksanakan pada bidang perekonomian, pendidikan, dan sosial-keagamaan dengan menggunakan metode ADCB (Asset Based Community Development) dan PAR (Participatory Action Riset). Dari hasil yang diperoleh, penggunaan aplikasi pembelajaran online untuk membantu problem masyarakat di bidang pendidikan baik itu di sekolah dasr, menengah pertama dan atas serta Taman Pendidikan Al-Quran. Adapun aplikasi yang digunakan diantaranya adalah Google Form, Google Meet, Google Classroom, Ms. Office Power Point dan Aplikasi Kinemaster. Sedangkan di bidang ekonomi telah menghasilkan kegiatan sosialisasi strategi pemasaran online berbasis pemanfaatan media sosial, program bantuan lembaga zakat dan pengurusan akte pendidrian koperasi di notaris. Pada bidan terakhir yaitu sosial keagamaan lebih menekankan pada pelaksanaan sosialisasi pengurusan perizinan penyeenggaraan walimatu'ursy di tengah pandemi dan pembelajaran Ilmu Tajwid secara virtual. Dapun output kefiatan terdiri dari Karya Tulis Ilmiah, Video Tutorial, Manual Book, Kontenkonten edukasi berbasis pemanfaatan media online. Respon terhadap kegiatan sangat baik terbukti dari ratusan views, likes, comments yang diberikan kepada penayangan kegiatan- kegiatan melalui channel YouTube dan media social lainnya (Instagram, Facebook, Whatsapp, dll).
\end{abstract}

Kata kunci: Covid-19; KKN-DR; Ekonomi; Pendidikan; Sosial-Keagamaan, 


\begin{abstract}
During the pandemic of Covid-19, various activities ranging from work, study, worship and socializing are recommended to be carried out from home as an effort to prevent the spread of the virus. Community Service Activities in the Era of the Covid-19 Pandemic of STAIN Sultan Abdurrahman Riau Island at Blue-Group are also carried out based on program development from home or known as KKN-DR (real work lectures from home). Thus, college duties and efforts to prevent the spread of Covid-19 can both be realized. Community service and empowerment activities based on economic, educational and socio-religious fields using the ADCB (Asset Based Community Development) and PAR (Participatory, Action Research) methods. From the results obtained, the use of online learning applications to help community problems in the field of education, both in elementary, junior high and high schools and the Al-Quran education school. The applications used include Google Form, Google Meet, Google Classroom, Ms. Office PowerPoint and Kinemaster Application. Whereas in the economic sector, it has produced socialization activities for online marketing strategies based on the use of social media, helping programs for SME's from zakat institutions and management of cooperative deeds in notaries. In the last midwife, namely socialreligion, emphasizes the implementation of socialization of licensing management of walimatu'ursy in the midst of a pandemic and learning Tajwid Science virtually. The output of activities consists of scientific papers, video tutorials, manual books, educational content based on the use of online media. The response to activities is very good as evidenced by the hundred numbers of views, likes, comments given to broadcasting activities through YouTube channels and other social media (Instagram, Facebook, Whatsapp, etc).
\end{abstract}

Keywords: Covid-19; KKN-DR; Economy; Education; Social-Religious.

\title{
Pendahuluan
}

Di masa pendemi Covid-19, berbagai aktifitas mulai dari bekerja, belajar, beribadah, hingga bersosialisasi dianjurkan untuk dilakukan dari rumah sebagai upaya pencegahan penyebaran virus. Kegiatan KKN di Era Pandemi Covid-19 Kelompok Biru STAIN Sultan Abdurrahman Kepulauan Riau juga dilakukan berbasis pengembangan program dari rumah atau dikenal dengan istilah KKN-DR (kuliah kerja nyata dari rumah). Dengan demikian kewajiban kuliah dan upaya pencegahan penyebaran Covid-19 samasama dapat terlaksana. Kegiatan pengabdian dan pemberdayaan masyarakat dilaksanakan pada bidang perekonomian, pendidikan, dan sosial-keagamaan.

Usaha ekonomi produktif yang dimiliki perseorangan maupun berbadan hukum dilaksanakan pada masa sebelum Covid-19 (corona virus disease 2019) hingga saat masa Covid-19 ini sangat sangat jauh berbeda mulai dari kurangnya minat konsumen terhadap produk yang ditawarkan, kurangnya konsumen berdatangan secara langsung hingga pembatasan kegiatan sosial berskala besar yang disebabkan dari dampak Covid-19 yang sedang melanda indonesia umumnya dan khususnya di tanjungpinang. kondisi ini disebabkan oleh anjuran beraktifitas di luar rumah dan social distancing (menjauhi kerumunan) guna untuk memutuskan mata rantai penyebaran Covid-19 sebagai mana tertuang dalam Peraturan Menteri Kesehatan Republik Indonesia Nomor 9 tahun 2020 tentang Pedoman pembatasan sosial berskala besar dalam rangka percepatan penanganan corona virus disease 2019 (Covid-19) tanggal 3 April 2020. Pandemi Covid-19 telah memberikan dampak terhadap aktivitas jual-beli di tengah masyarakat pada saat euphoria berbisnis sangat 
tinggi yang ditandai dengan meningkatnya aktivitas kewirausahaan dan kemampuan menyusun rencana bisnis (bisnis plan) terutama dikalangan muda seperti mahasiswa (Kamaruzaman, 2020).

Disisi lain kondisi perekonomian Indonesia sebagaimana tersebut di atas, telah menimbulkan berbagai problem sosial yang kompleks, misalnya timbul tingkat pengangguran yang tinggi, bertambahnya angka kemisikinan, produktivitas dan kualitas tenaga kerja yang rendah, serta merosotnya usaha kecil dan menengah yang menjadi tumpuan rakyat. Maka perlu ada cara untuk bertahan dengan merancang strategi dalam berusaha ataupun menghidupkan sistem usaha yang berbasis gotong royong. Sistem ekonomi kerakyatan di negara ini memang secara umum sangat cocok dengan badan usaha yang berbentuk koperasi Prinsip usaha dan karakter koperasi yang berbeda dengan badan usaha lainnya membuat badan usaha ini disenangi oleh masyarakat Indonesia yang melaksanakan seluruh kegiatan perekonomiannya berdasarkan sistem ekonomi kerakyatan. Untuk itu perlu ada program penguatan koperasi (Andhini, 2013).

Bagi masyarakat kecil yang belum memiliki modal atau kekurangan modal dalam menjalankan usahanya maka dari itu didalam KKN ini di ajukanlah dana zakat sebagai upaya membantu masyarakat kecil dalam menjalankan usahanya. Bagaimana peran Badan Amil Zakat Nasional (BAZNAS) Kota Tanjungpinang didalam menyalurkan bantuan dimasa pandemi terhadap Usaha Kecil Menengah (UKM) Di Kelurahan Air Raja. Pada kelurahan ini banyak dijumpai berbagai bentuk UKM. Sebelum Covid-19 usaha UKM berjalan dengan lancar namun setelah adanya anjuran untuk tidak keluar rumah dan melakukan social distancing maka sebagian besar UKM mengalami penurunan pendapatan usahanya. Atas sebab tersebut, UKM di Kelurahan Air Raja sangat membutuhkan bantuan dari berbagai pihak semisalnya dari BAZNAS untuk membantu dampak penurunan perekonomian karena Covid-19 (Fahham, 2011).

Didalam pelaksanaan pendidikan di masa Covid-19, dampak yang cukup besar karena pendemi Covid-19 adalah pada dunia pendidikan. Berikut dampak ikutannya yaitu tuntutan untuk mampu menggunakan perangkat pendidikan jarak jauh. Permasalahannya adalah keterbatasan pengetahuan dan kemampuan tenaga pendidik terhadap pemanfaatan media pembelajaran yang berbasis online. Maka dari itu perlua ada sosialisasi penggunaan berbagai aplikasi pembelajaran yang dapat digunakan oleh guru dan siswa misal Google Meet menjadi pengganti tatap muka. Aplikasi yang terintegrasi dengan G-suite ini memungkinkan para pengguna untuk dapat bergabung langsung melalui undangan yang dapat dikirim melalui email ataupun Whatsapp Group dengan memberikan tautan atau kode rapat yang dikirimkan. Google Meet telah menjadi versi yang lebih baik dikarenakan mampu menampilkan pada berbagai jenis prosesor baik berbasis web, android maupun IOS (Hendrik Pandu Aksi. Lita Ariyanti, 2020)

Pada masa pandemi Covid-19, setiap kegiatan belajar mengajar (KBM) pada tingkat pendidikan apapun senantiasa membutuhkan platform pembelajaran berbasis aplikasi baik online maupun offline. Pemanfaatan aplikasi komputer untuk menunjang pembelajaran seperti Microsoft dapat menjadi mantra ajaib untuk bahan ajar yang dapat dihasilkan guru. Pembuatan bahan ajar dengan menggunakan PowerPoint dapat untuk bahan slide presentasi guru saat mengajar melalui Google Meet dan Zoom atau hanya sekedar membagikan file untuk siswa mempelajarinya dirumah. Saat ini versi PowerPoint telah mencapai pada Versi terakhir tahun 2019. Di mana versi terbaru ini membuat tampilan lebih menarik dan interaktif sehingga dapat membuat siswa tetap dapat menyerap pelajaran dengan baik. Tantangan yang paling penting adalah bagaimana upaya untuk membuat para guru mampu mengoperasikan PowerPoint untuk membuat bahan ajarnya dengan berbagai kerumitan perintah yang terdapat didalamnya. Untuk itu sangat perlu ada sosialisasi dan petunujk penggunaan aplikasi ini bagi guru (Mustaqim \& Prianto, 2015).

Kegiatan pendidikan yang lainnya seperti pendidikan agama di TPQ (Taman Pendidikan Al-Qur'an) yang melaksanakan pengajaran yang tepat di masa pandemi Covid-19 maka perlu juga dibuat rancangan pembelajaran yang efektif dan efisien yang dapat digunakan oleh guru TPQ. Pemberian materi Pendidikan Agama Islam berupa video berikut bahan ajarnya dalam sekali tayang menjadi alternatif bagi guru TPQ untuk memastikan kegiatan pembelajaran tetap dapat dilaksanakan. Salah satu aplikasi yang dapat digunakan 
adalah Kinemaster untuk membuat video pembelajaran visualisasi bagi siswa. Hasil video akan disebarkan secara daring melalui platform media sosial seperti Facebook, Instagram dan YouTube yang memungkinkan untuk dijangkau siswa. Dalam pembuatan video pembelajaran maka perlu disosialisasikan kepada guru tutorial menggunakan aplikasi editing video Kinemaster ini dikenal juga sebagai program penyuntingan video secara profesional yang bisa digunakan di smartphone (Laily Amin Fajariyah, 2018).

Adapun permasalahan lainnya yang akan dibuat kegiatan dalam program KKN ini yaitu keterbatasan pengetahuan wali murid terhadap penggunaan aplikasi media pembelajaran berbasis online Google Classroom yang diberikan guru.. Untuk menyikapi hal ini, melalui program KKN-DR ini adalah dengan pembuatan buku panduan dan video tutorial tentang penggunaan Google Classroom dirasakan akan sangat membantu bagi orang tua sebagai pendamping pembelajaran online di rumah. Google Classroom merupakan layanan web yang dikembangkan untuk sekolah oleh Google untuk mendistribusikan, menyedehanakan dan membuat serta menilai tugas tanpa tatap muka dan merupakan layanan web yang bersifat gratis. Tujuan utama dari aplikasi ini adalah mempermudah proses berbagi file antara guru dengan siswa ataupun sebaliknya (Azhar Arsyad, 2002).

Selanjutnya didalam bidang keagamaan justru juga dilaksanakan dari rumah, mengingat dan menimbang penyebaran Covid-19 ini semakin pesat, sehingga dalam pelaksanaaan ini diharapkan mampu ikut serta dalam memutuskan mata rantai penyebaran Covid-19 terutama pada tempat pembelajaran mengaji bagi santri-santri TPQ. Banyak sekali tempat untuk pembelajaran mengaji dinonaktifkan bahkan ditutup pada masa Covid-19 ini. Maka melalui kegiatan KKN kali ini, akan dirancang pembelajaran secara daring/online dengan pembuatan buku Tutorial dan Video Pembelajaran Tajwid online yang dibagikan kepada para santri yang belajar di TPQ diharapkan dapat membantu pembelajaran di TPQ tersebut dapat kembali aktif walaupun hanya dilakukan dari rumah (Amin, 2019)

Di kegiatan keagamaan lainnya yang akan dibahas dalam KKN kali ini adalah berkaitan dengan penyelengaraan Walimatursy di tengah pandemi berupa sosialisasi aturan positif dan pandangan agama tentu akan sangat berguna bagi msyarakat. Terkait dengan pelaksanaan walimah dimasa wabah pandemi ini, Kementrian Agama Indonesia menyatakan tergantung keputusan setiap kepala darerah masing-masing. Khususnya di Kota Tanjungpinag Provinsi Kepulauan Riau, terdapat aturan yaitu Perwako (Peraturan Wali Kota) Tanjungpinang Nomor 29 Tahun 2020 tentang Pedoman tatanan hidup baru yang memuat aturan pembatasan kerumunan. Hal ini tentunya juga terkait pelaksanaan resepsi pernikahan maupun hiburan yang melibatkan masyarakat banyak yang diperbolehkan namun harus mengikuti sejumlah persyaratan dalam ketentuan yang berlaku (Perwako Tanjung Pinang No. 29, 2020).

\section{Metode}

KKN-DR Era Covid-19 tahun 2020 STAIN Sultan Abdurrahman Kepulauan Riau yang telah dilakukan oleh Kelompok Biru dengan Kelurahan Air Raja sebagai mitra dampingan telah menggunakan 2 (dua) metode yaitu Metode ABCD (Asset Based Community Development) dan Metode PAR (Partipatory, Action, Research). Kedua metode ini diterapkan pada 9 kegiatan utama KKN-DR dari setiap anggota kelompok. Ada 7 (tujuh) anggota mengunakan ABCD dan 2 (dua) anggota menggunkan PAR.

\section{Metode ABCD (Asset, Based, Community, Drivent Devloment)}

Dalam strategi pendekatan yang dilakukan, kali ini kami melakukan pendekatan dengan metode yang di sebut $A B C D$ atau Pendekatan dalam pemberdayaan masyarakat difokuskan pada pengembangan aset yang dimiliki masyarakat sebagai basis utama pengembangan program. Ada 5 (lima) tahapan ABCD: Pertama, Inkulturasi (Pengenalan) yaitu tahap dimana dibutuhkan komunikasi yang secara mendalam terhadap seluruh kegiatan juga menjadi sebuah faktor yang sangat mencolok, guna untuk membangun kepercayaan. Apabila kepercayaan sudah terbangan maka akan sangat mudah mendapatkan suatu informasi 
yang sangat mendalam. Kedua, Discovery (Mengungkapkan Informasi) yaitu dalam tahap ini dapat melakukan sebuah perencanaan yang lebih matang. Hal yang paling utama dilakukan adalah dengan melakukan identifikasi-identifikasi informasi penting yang menjadikan landasan-landasan dalam suatu perencanaan. Secara garis besar pada tahap ini terdiri dari pengungkapkan keberhasilan yang pernah diraih, menelaah suatu elemen yang bersifat khusus tentang asset yang bisa di kembangkan dan pemetaan asset. Ketiga, Design (Mengetahui Asset dan Mengindentifikasi peluang) yaitu tahapan dimana melakukan penggolongan dan mobilisasi asset sehingga terbentuk visi serta misi masa depan bagi sasaran KKN-DR. Keempat, Define (Mendukung keterlaksanaan program kerja) yaitu tahap yang diharapkan masyarakat/sasaran KKN sudah bisa membayangkan dunia usahanya dengan cara yang berbeda juga sehingga masyarakat memandang program ini akan menjadi prioritas utama dalam mengembangkan Program. Dengan memiliki komitmen yang tinggi juga bisa saling bekerjasama. Kelima, Refleksi (Hasil) yaitu di dalam strategi pendekatan ini peserta KKN akan memonitoring hasil dari perkembangan dan kinerja outcome, sejauh mana perkembangan kegiatan KKN-dr ini berjalan apasaja hasi; yang telah di dapatkan dan seberapa luasnya manfaat yang di rasakan oleh sasaran KKN-DR khususnya, dan masyarakat umumnya (P3M STAIN, 2020).

\section{Metode PAR (Participatory Action Research)}

Metode PAR merupakan kegiatan riset yang berbeda dengan metode penelitian ilmiah lainnya yang biasa dilakukan oleh para akademisi, lembaga survey, dll. Di dalam metode penelitian ilmiah pada umumnya seorang researcher menjadikan suatu kelompok masyarakat hanya sebagai objek yang diteliti untuk mendapatkan suatu inti permasalahan tanpa memberikan perubahan (transformasi) nilai di dalam suatu masyarakat tersebut, Di dalam kegiatan PAR, peneliti/praktisi PAR tidak memisahkan diri dari situasi masyarakat yang diteliti, melainkan melebur ke dalamnya dan bekerja bersama warga dalam melakukan PAR (P3M STAIN, 2020).

\section{Hasil dan Pembahasan}

Hasil dari kegiatan KKN-DR di masa pandemi COVID-19 ini menghasilkan kegiatan dalam beberapa bidang seperti Perekonomian, Pendidikan, serta Sosial-Keagamaan dengan rinsian kegiatan sebagai berikut: Pertama, Bidang ekonomi terdiri dari kegiatan-kegiatan a) Upaya membantu UKM dalam aspek pemasaran produk. b) Sosialisasi kepengurusan akta notaris bagi pelaku usaha UMKM. c) Sosialisasi program bantuan kepada BAZNAS bagi UMKM. Kedua, Bidang pendidikan terdiri dari kegiatan-kegiatan:

a)Tutorial penggunaan Google Meet. b) Tutorial penggunaan Google Classroom. c) Tutorial penggunaan Kinemaster. d) Tutorial penggunaan PowerPoint. Ketiga, Bidang Sosial-Keagamaan terdiri dari kegiatan- kegiatan: a) Pembelajaran ilmu tajwid. b) Sosialisasi pengurusan perizinan penyelenggara walimatursy ditengah pandemi. Didalam pembahasan kegiatan yang di laksanakan pada setiap bidang pastinya berbeda, namun di dalam penerapannya sama-sama menggunakan media sosial sebagai basis utama di dalam pelaksanaanya. Hal ini dikarenakan sesuai dengan paduan kegiatan KKN dari rumah yaitu membangun kegiaan dengan menggunakan platfrom media sosial lainnya.

\section{Bidang Ekonomi}

Kegiatan pengabdian dilakukan kurang-lebih 4 (empat) minggu, pada setiap kegiatan dilakukan secara signifikan antara kegiatan langsung dan kegiatan secara tidak langsung dalam program kerja KKNDR ini mendapatkan hasil yang sangat baik, dikarenakn bagi pedagan bisa mengaplikasikan dalam setiap kegiatan jualbelinya dilakukan secara online atau menggunakan sosial media. Kegiatan KKN-DR ini mampu memberikan kontribusi yang sangat baik bagi pengusaha UMKM atau sasaran kegiatan KKN pedagang dalam mempromosikan dagangannya sehingga sedikit meningkatkan. Kegiatan ini juga mampu mengenalkan kepada masyarakat banyak tentang produk yang di jual oleh pedagang kecil (UKM). Pemilihan media social 
sebagai platform penjualan online produk UMKM menjadi jawaban terhadap permasalahan dampak pandemi COVID-19. Saluran penjualan online tentunya dapat meningkatkan penjualan pedagang. Untuk itulah kegiatan ini berfokus pada penggunaan social media sebagai alternative penjualan ditengah pandemi yang telah diajarkan kepada pelaku UKM melalui video yang ditayangkan di media sosial. Respon yang diperoleh sangat positif terlihat dari tingginya jumlah viewer yang mencapai angka 285 views. Serta 64 orang yang menyukai (Budiyanti, 2020).

Begitupula dengan sosialisasi pembuatan akta notaris disini fokus penulis kepada salaha satu koperasi yang ada dikelurahan Air Raja yaitu Koperasi Konsumen UKM Penjahit Bertuah Jln arah Uban Km.10 ruko No.3. UKM atau koperasi ini lebih fokus kepada menjahit baju-baju seragam sekolah, baju-baju dinas yang jumlah besar. Koperasi mempunyai anggota penjahit lebih dari 5 orang untuk menjahit baju pesanan. Dalam bentuk KKN-DR yang telah dilakukan dan kesesuaiannya dengan tujuan dan hasil yang di harapkan agar masyarakat khusunya para koperasi yang berada di kelurahan Air Raja yang belum mempunyai akta atau belum di naungi badan hukum ini (Nasrizal, 2005). Koperasi tersebut mau dan memiliki kesadaran bahwa pentingnya akta pendirian koperasi dari notaris. Dari video sosialisasi pengurusan akta notaris diperoleh respon penonton yang positif menyambut baik adanya sosialisasi tersebut. Dan permasalahan mereka tidak mengetahui alur pengurusan akta dan izin koperasi menjadi terjawab (Ratangin, 2017).

Hal demikian juga dilakukan pada kegiatan Sosialisasi program bantuan kepada BAZNAS bagi UMKM, dalam kegiatan ini berdeba dalam pendekatan nya yang dimana metode ini menggunakan metode PAR atau Participatory Action Research, dari hasil pelaksanaan yang dipatkan bahwasanya wabah pandemi COVID-19 ini sangat berdampak pada kegiatan usaha kecil dan menenggah.maka diharapkan ada perhatian dari pemerintah ataupun badan bantuan lainnya untuk membantu para pelaku usaha UKM di masa pandemi ini (Chaniago, 2015). Seperti halnya bantuan yang di salurkan oleh salah satu Lembaga Zakat kota Tanjungpinang terhadap usaha UKM dimasa pandemi ini. Meskipun belum secara keseluruhan para pelaku usaha UKM ini menerima bantuan tersebut dikarenakan melihat dari kondisi dan juga kreteria dari pelaku usaha UKM yang bisa mendapatkan bantuan (Shaleh, 2001). Akan tetapi dengan adanya program tersebut sangat membantu para pelaku usaha UKM yang terdampak pada masa pandemi ini (Fahham, 2011).

\section{Bidang Pendidikan}

Proses pembelajaran di masa pandemi ini juga di laksanakan dari rumah, hal demikian juga merupakan salah satu cara pencegahan dari penyebaran virus COVID-19 dari hal ini maka pembelajaran menggunakan platfrom media sosial manjadi nomor satu di masa sekarang, seperti pembelajaran menggunakan Google Classroom Dengan adanya program ini keterbatasan pengetahuan wali murid terhadap penggunaan aplikasi Google Classroom khususnya menjadi teratasi. Namun juga terdapat kendala-kendala yang dihadapi dalam pelaksaan program ini sehingga program tidak berjalan secara optimal. Contoh permasalahan yang dihadapi salah satunya yaitu tahapan perencanaan yang tidak dapat dilaksanakan seperti perkenalan secara door to door pada tahap inkulturasi atau perkenalan. Namun secara umum, kegiatan tutorial penggunaan Google Classroom bagi orang tua sudah terlaksana dalam bentuk video dan buku tutorialnya. Dari hasil respon pennton banyak mendapatkan views dan yang menyukai (likes) (Rakhmawati Purba, Aisyah Siregar, Rumiris Siahan, Suci Etri Jayanti S., 2020).

Disisi lain penggunaan Google Meet juga menjadi faktor pendukung keterlaksanaan pembelajaran dari rumah, Tujuan dari pelaksanaan KKN-DR dengan pembuatan tutorial penggunaan aplikasi Google Meet ini serta Sosialisasi penggunaan Google Form dalam bentuk video adalah untuk memberikan pengetahuan dan pelatihan secara online bagi tenaga kependidikan mengenai cara pengoperasian aplikasi Google Meet sebagai salah satu media pembelajaran yang digunakan pada masa pendemi COVID-19 ini. Kegiatan tutorial penggunaan Google Meet telah berhasil dilaksanakan ditandai dengan terbentuknya video dan buku manual 
penggunaan aplikasi tersebut dan respon dari penonton dan pengguna yang positif. Google Meet sangat bagus untuk guru yang menginginkan pembelajaran dengan visualitas dan audiositas yang tinggi karena aplikasi ini memungkinkan guru untuk menampilkan gerakan percontohan pembelajaran, share screen (membagikan jendela) hasil yang sudah terekap dan penjelasan dengan suara yang lebih lama (Team eLearning UIN Malang, 2020).

Dalam pembelajaran yang menarik di masa pandemi ini adalah bagaimana cara pengaplikasian Microsoft yang tersedia pada laptop atau PC. Program PowerPoint merupakan program yang di gunakan untuk membuat slide atau presentasi yang di keluarkan oleh microsft sebagai produsernya. Saat ini versi PowerPoint telah mencapai pada versi 2010. Di mana versi di gunakan dalam versi terbaru ini, sehingga tampilan akan lebih menarik dan lebih interaktif. Penggunaan yang paling penting mengoperasikan PowerPoint 2003 adalah mengolah slide sebagai bahan pembelajaran. Pembuatan slide yang polos tanpa diberi efek dan kurang menarik, oleh karena itu anda perlu merubahnya menjadi tampilan menarik. Video dan buku tutorial penggunaan PowerPoint untuk mengetahui bagaimana penggunaan PowerPoint untuk membuat materi pembelajaran yang menarik. Fitur PowerPoint tergolong lengkap, karena guru dapat mengisi audio dan video penjelasan materi sehingga murid dapat melihat dan mendengar guru sekalipun melalui pembelajaran jarak jauh. Kegiatan ini mendapat respon baik dari para guru sasaran yaitu dengan banyaknya penonton video produk KKN dan yang menyukainya. Selain itu respon positif ditandaik juga dengan komen positif penonton (Mustaqim \& Prianto, 2015).

Dimasa pandemi seperti ini,selain hanya memanfaatkan media sosia tentunya juga harus memberikan keretarikan terhadap pembelajaran itu sendiri seperti pembelajaran yang menarik, Sosialisasi berupa pemberian materi Pendidikan Agama Islam berupa video dan akan disebarkan secara daring melalui platform media sosial dalam pempelajaran ini memanfaatkan aplikasi Kinemaster yang dimana belum banyak yang menegetahui keguanaan atau keunggulan aplikasi ini, dalam pelaksanaan Program - program kerja yang penulis laksanakan adalah berupa membuat video-video tutorial dan mengajar di TPQ, yang menjadi mitra sasaran KKN tahun ini. Kegiatan ini telah sukses dilaksanakan yaitu dengan mengudaranya video tutorial dan terbentuknya buku manual penggunaan aplikasi Kinemaster bagi pembelajaran di TPQ.

Respon guru menyambut baik kemajuan teknologi pembelajaran dengan aplikasi ini hal itu ditandai dengan banyaknya penonton dan yang menyukai tintonan serta buku tutorial penggunaan aplikasi ini (Laily Amin Fajariyah, 2018).

\section{Bidang Sosial-Keagamaan}

Dalam pelaksanaan kegiatan di bidang keagamaan tentunya juga tidak terbelakang kan khususnya di masa pandemi seperti ini diantaranya seperti pembelajaran terhadap TPQ yang belum melaksanakan kegiatan secara langsung karna pandemi ini (Amin, 2019). Maka kegiatan KKN tahun ini dilakukan secara daring/online yang diharapkan bisa membantu santri-santri TPQ dapat kembali aktif dapat dilakukan dirumah. Dalam pelaksanaannya banyal memanfaatkan sosial media walaupun ada beberapa kegiatan yang harus terjun kelapangan dan tetap mengikuti protokol kesehatan. Didalam pelaksanaan kegiatan peserta KKN DR memanfaatkan media sosial seperti YouTube, Facebook, Whatsapp, dan Instagram sebagai langkah untuk membantu pengajaran bagi guru dan santri TPQ, Pembelajaran memalui video-video tentang pembelajaran tajwid sehingga bisa di bagikan ke santri santri yang sedang belajar mengaji. Video pembelajaran Ilmu Tajwid secara virtual di TPQ ini mendapat sambutan hangat dari guru dan santri, hal ini terlihat dari antusiasme mereka menonton dan menyukai video pembelajaran serta membaca buku pembelajaran Ilmu Tajwid yang juga disertakan dalam deskripsi video sehingga memungkinkan bagi para guru untuk mencontohinya (Amin, 2019).

Disini kegiatan sosial berbasis agama lainnya seperti pelaksanaan Sosialisasi pengurusan perizinan penyelenggaraan Walimatursy melakukan suatu program kerja yang sesuai dengan draft pedoman KKN Era 
COVID-19 STAIN SAR Kepri, mengambil program bidang keilmuan dibagian karya tulis ilmiah KTI) dengan tema "Walimatursy Dimasa Pandemi Apakah Harus diadakan". KTI ini merupakan analisa hukum agama dan Negara dalam menyikapi isu pandemi terhadap pelaksanaan kegiatan pernikahan dan walimatu'ursy ditengah wabah yang melanda suatu negeri. Kota Tanjungpinang sendiri telah menerbitkan Peraturan Walikota untuk perizinan penyelenggaraan pesta pernikahan dengan beberapa aturan yang membatasi. Jadi didalam KTI ini banyak membahas kajian hukum agama terhadap penyelenggaraan walimatu'ursy secara komprehensif dan kontemporer melihat dari hukum Negara atau produk hukum yang diterbitkan oleh ulil amri (pemerintah). Dari perwako tersebut kemudian kegiatan sosialisasi pengurusan izin dilaksanakan dengan tujuan untuk memberikan panduan bagi masyarakat yang akan menyelenggarakan pesta pernikahan agar memperhatikan ketentuan yang berlaku. Video sosialisasi ini mendapat respon positif penonton dengan menjadi pengetahuan bagi mereka tentang tatacara pengurusan izin walimah dan mereka menyukai video ini serta memberikan komentar positif (Perwako Tanjung Pinang No. 29, 2020).

Secara garis besar ada beberapa kegiatan yang di lakukan dalam pelaksanaan KKN-DR ini seperti sosialisasi menggunakan aplikasi YouTube atau secara virtual dari setiap program kerja sesuai dengan tema yaitu untuk Mengptimalisasi kontribusi melalui pengembangan program dari rumah bagi masyarakat Kelurahan Air Raja Kota Tanjungpinang serta respon dari setiap kegiatan. Banyak masyarakat yang memberi perhatian lebih pada bidang perekonomian dalam pelaksanaan program KKN-DR ini. Banyaknya mendapatkan perhatian dan respon dari masyarakat ramai dapat dipastikan karena dampak ekonomilah yang sangat dirasakan oleh hampir seluruh lapisan masyarakat. Kesulitan mereka menghadapi perubahan masa yang mengubah sistem menuntut mereka untuk bias bertahan. Pemberian pendampingan terhadap strategi perancangan produk, perencanaan produksi dan mencari strategi untuk memasarkan atau manajemen pengambilan strategi yang tepat di masa pandemi ini, maka dari itu kegiatan KKN-DR di bidang perekonomian ini menjadi faktor yang sangat di butuhkan oleh hampir seluruh lapiran masyarakat, selanjutnya disusul pada kegiatan di bidang pendidikan serta perekonomian. yang di publikasikan melalui YouTube dan di tuangkan dalam bentuk screen shoot dan grafik. Selain itu terdapat juga berbagai output kegiatan berupak KTI, Manual Book dan dokumentasi lainnya.

Adapun list kegiatan dalam channel YouTube Kelompok Biru dapat dilihat pada gambar berikut:

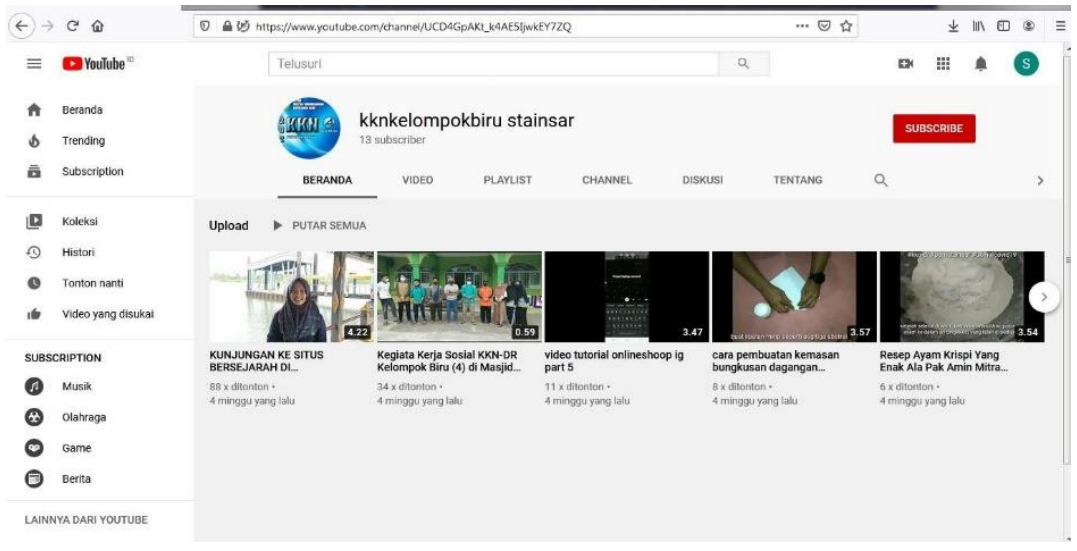

Gambar 1. Channel YouTube Kelompok Biru: \#kknkelompokbiru Stainsar

Dari gambar diatas menunjukkan Channel YouTube Kelompok KKN Biru yang mana semua kegiatan yang telah dilaksanakan didokumentasikan dan diupload disana untuk dapat ditonton oleh sasaran KKN dari tempat dimana mitra dampingan berada yaitu Kelurahan Air Raja. Semua peserta diarahkan untuk mengupload di channel milik kelompok ini sekalipun mereka telah mengupload di channel milik sendiri. Dari respon penonton di chanell kelompok juga diperoleh banyak views, likes dan comments. Namun perolehan respon penonton yang dikalkulasikan adalah berdasarkan dari chanbel milik peserta masingmasing. Diantara output kegiatan yang disajikan dalam channel grup ini yaitu bidang pendidikan terdapat video Penggunaan aplikasi pembelajaran Google Meet, Google Classroom, Google Form, PowerPoint, 
Kinemaster. Bidang ekonomi terdapat video pembuatan online-shop, sosialisasi pengurusan program zakat bantuan bagi UKM, sosialisasi pengurusan akta koperasi di Notaris. Sedangkan untuk output bidang socialkeagamaan terdapat Video pembelajaran Ilmu Tajwid dan Sosialisasi pengurusan perizinan penyeenggaraan Walimatu'ursy. Selain output kegiatan masing-masing peserta juga terdapat output kegiatan bersama yaitu kunjungan Wisata Sejarah ke Istana Kota Rebah Kota Tanjung Pinang dan Video Gotong Royong di suatu Masjid di Kelurahan Air Raja. Kegiatan ini merupakan kegiatan tambahan untuk bakti social kelompok biru terhadap masyarakat dengan melakukan gotong royong di tempat ibadah umat musli yaitu Masjid dan kunjungan wisata sejarah ditempat bekas peninggalan sejarah dengan melakukan sedikit kegiatan sosial berupa pembersihan sampah yang kecil yang tertinggal.

Dalam pelaksanaan kegiatan KKN ini dilakukan suatu pengukuran tingkat terlaksananya program dan umpan balik sasaran terhadap output kegiatan yang sudah diupload di media sosial baik itu melalui channel individu maupun channel media sosial kelompok. Namun perolehan hasil respon sasaran terhadap output kegiatan KKN-DR yang dihitung berdasarkan hasil rekapitulasi dari channel masing-masing peserta karena lebih fokus diberikan kepada sasaran dalam pelaksanaan kegiatan secara individu. Selain itu channel individu juga lebih mendapat perhatian dari sasaran karena sudah mengenal dan diinformasikan terlebih dahulu sebelumnya. Hal ini tujuannya untuk mendapatkan perhitungan yang tepat terhadap respon sasaran kegiatan.

Rekapitulasi Perolehan hasil Kegiatan KKN-DR Kelompok Biru secara keseluruhan dapat disimak melaluigrafik yang terdapat di bawah ini:

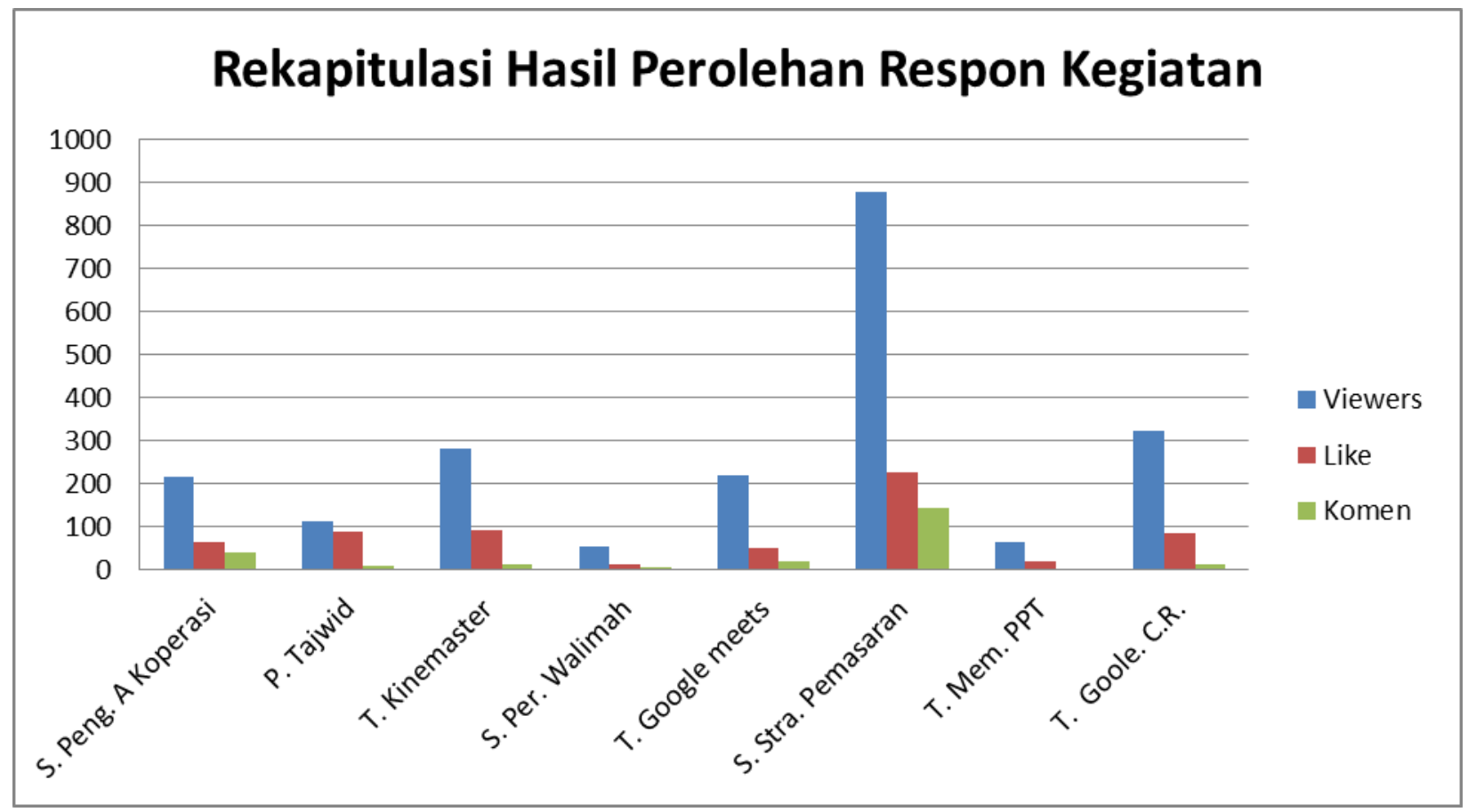

Gambar 2. Rekapitulasi Hasil Perolehan Respon Sasaran terhadap Output Kegiatan KKN-DR Kelompok Biru

Dari gambar di atas menunjukkan hasil rekapitulasi perolehan respon sasaran terhadap output kegiatan KKN-DR Kleompok Biru yang sudah dilaksanakan. Output tentang strategi pemasaran mendapat perolehan views yang tinggi yaitu 285 kali, 238 kali, 114 kali, 93 kali, 93 kali, 88 kali, 103 kali, 73 kali, 60 kali dengan total secara kesulurahan 1.147 kali. Kemudian diikuti video pengunaan Google Classroom sekitar 300 kali. Dan output kegiatan lainnya rata-rata mendapat views rentang jumlah dari 100 - 300 kali. Respon diperkuat lagi dengan pemberian like yang menunjukkan sasaran menyukai output kegiatan rentang yang menyukai dari 60 - 200 likes. Perolehan tertinggi likes juga diterima oleh video strategi pemasaran 
online secara keseluruhan mencapai lebih 200 likes, setelah itu diikuti video Google Classroom dan videovideo lainnya dari rentang jumlah 50 - 100 likes.

Tabel 1.

Jadwal Pelaksanaan Kegiatan Pendampingan

\begin{tabular}{|c|l|l|}
\hline Pertemuan & \multicolumn{1}{|c|}{ Hari, Tanggal } & Materi \\
\hline I & Senin, 12 Oktober 2020 & Mencari mitra dampingan \\
\hline II & Selasa, 13 Oktober 2020 & Pengenalan tentang kegiatan KKN-DR era COVID-19 \\
\hline III & Rabu, 14 Oktober 2020 & Mencari dan mengungkapkan informasi \\
\hline IV & Kamis, 15 Oktober 2020 & Membuat analisis Strategi \\
\hline V & Jum'at, 16 Oktober 2020 & Pengembangan aset di bidang perekonomian \\
\hline VI & Senin, 19 Oktober 2020 & Pengembeangn aset di bidang pendidikan \\
\hline VII & Selasa, 20 Oktober 2020 & Pengembangan aset bidang keagaan \\
\hline VIII & Rabu, 21 Oktober 2020 & Evaluasi kegiatan pelaksanaan \\
\hline
\end{tabular}

\section{Kesimpulan}

1. Dalam pelaksanaan kegiatan KKN-DR tahun ini menawarkan kegiatan sebanyak 20 (dua puluh) produk diantaranya video cara pembuatan kemasan, membuat onlineshoop melalui sosial media dan lain sebagainya, ini merupakan suatu program kerja yang dimana dilakukan secara virtual atau online, sehingga bisa mempermudah pengusaha UMKM dalam memasarkan usahanya dan menjadi salah satu bentuk pencegahan penyebaran mata rantai Covid-19 karena tidak berkontak secara langsung antara Pengusaha UMKM dan Konsumen selain itu juga memberikan sosialisasi secara virtual kepada pelaku usahan UMKM.

2. Setelah dilakukannya program kerja ini, akhirnya banyak masyarakat yang awam mengetahui bagaimana tata cara prosedur pembuatan akta koperasi di notaris, dan bagaimana mendirikan sebuah koperasi. Dan para anggota-anggota koperasi pun bisa memahami kenapaperlunya mereka mendirikan akta koperasi di notaris.

3. Dari hasil pelaksanaan yang didapatkan bahwasanya wabah pandemi Covid-19 ini sangat berdampak pada kegiatan usaha kecil dan menenggah.maka diharapkan ada perhatian dari pemerintah ataupun badan bantuan lainnya untuk membantu para pelaku usaha UKM di masapandemi ini. seperti halnya bantuan yang di salurkan oleh salah satu Lembaga Zakat kota Tanjungpinang terhadap usaha UKM dimasa pandemi ini.meskipun belum secara keseluruhan para pelaku usaha UKM ini menerima bantun tersebut, dikarenakan melihat dari kondisi dan juga kreteria dari pelaku usaha UKM yang bisa mendapatkan bantuan, akan tetapi dengan adanya program tersebut sangat membantu para pelaku usaha UKM yang terdampak pada masa pandemi.

4. Pelaksanaan kegiatana dengan aplikasi Google Meet merupakan aplikasi atau software lunak yang dikembangkan oleh google untuk melakukan layanan komunikasi terutama pada saat pandemi terutama untuk melakukan proses belajar dan mengajar. Google Meet ini dapat digunakan secara gratis unuk skala kecil sebanyak 25 peserta. Kelebihan Google Meet ini adalah dapat membantu para pendidik (guru) melakukan pembelajaran menggunakan video call, mempermudah melakukan pembelajaran dimana saja, dan Google Meet ini bisa diakses melalui smartphone/hp. 
5. Pemanfaatan microsoft yang terdapat di PC ataupun Android salah satu pendukung kegiatan pembelajaran, Program PowerPoint merupakan program yang di gunakan untuk membuat slide atau presentasi yang di keluarkan oleh microsft sebagai produsernya. Saat ini versi PowerPoint telah mencapai pada persi 2003. Di mana versi di gunakan dalam versi terbaru ini, sehingga tampilan akanlebih menarik dan lebih internatif. Penggunaan yang paling penting mengoperasikan PowerPoint 2003 adalah mengolah slide. Pembuatan slide yang polos tanpa diberi efek dan kurang menarik, oleh karena itu anda perlu merubahnya menjadi tampilan menarik.

6. Pandemi Covid-19 mengubah segala aspek kehidupan termasuk dalam dunia pendidikan dimana sistem pembelajaran dialihkan menjadi pembelajaran daring (dalam jaringan) perubahan yang terjadi secara mendadak ini menjadi permasalahan karena kurang siapnya wali murid sebagai pendamping pembelajaran dirumah untuk menjalankan sistem ini. Dengan demikian program pembuatan buku panduan dan video tutorial salah satu media pembelajaran online yang digunakan hampir pada seluruh sekolah mampu meningkatkan efektivitas kegiatan belajar mengajar dari rumah melalui peningkatan pengetahuan wali murid terhadap aplikasi ini.

7. Pelaksanaan KKN tahun 2020 kali ini menggunakan jenis KKN - DR (Kuliah Kerja Nyata Dari Rumah), yang mana mahasiswa diharuskan membuat konten - konten atau poster - poster kreatif yang nantinya akan dibagikan ke platform media sosial seperti Facebook, Instagram dan YouTube.

Adapun untuk melaksanakan program kerja peserta KKN DR untuk mengapdi ke masyarakat khususnya diwilayah sekitar rumah peserta yang akan dilakukan secara online dan membuat sebuah konten video pembelajaran dan tutorial yang di Upload di YouTube, Facebook, Instagram, dan semacamnya dikarenakan untuk melakukan akftivitas tidak seperti biasanya seperti kegiatan Sekolah, mengaji dan bekerja sehingga mereka tidak ada kegiatan khususnya dalam kegiatan mengajar mengaji (guru dan santri-santri TPQ).

8. Dalam kegiatan KKN-DR ini peserta pada kegiatan ini, melakukan suatu program kerja yang sesuai dengan draft pedoman KKN Era Covid-19 STAIN SAR Kepri, mengambil program bidang keilmuan dibagian karya tulis ilmiah, dengan tema "Walimatursy Dimasa Pandemi Apakah Harus diadakan". Dan dibuatlah suatu KTI yang membahas pengertian walimatursy, hukum walimah dalam Islam dan akhiri dengan penjelasan apakah harus diadakan walimatursy ini dimasa pandemi. Dengan mengambil rujukan buku, kitab, jurnal-jurnal yang membahas seputar walimatursy dan pandemi virus ini.

\section{Saran}

Demikianlah hasil dari penelitian yang telah dilakukan, besar harapan peneliti agar hasil dari penelitian ini dapat dikaji lebih baik lagi untuk ke depannya, sehingga dapat bermanfaat bagi khalayak ramai. Oleh karena itu, peneliti menyadari perlunya inovasi-inovasi yang lebih segar lagi agar tekhnik pemasaran di masyarakat dapat menjadi lebih efesien.

\section{Ucapan Terimakasih}

Penulis mengucapkan terima kasih kepada setiap pihak yang telah turut membantu dalam menyelesaikan pembuatan jurnal kegiatan "Optimalisasi Kontribusi Melalui Pengembangan Program Dari Rumah Bagi Masyarakat Kelurahan Air Raja Kota Tanjungpinang” 


\section{Referensi}

Amin, S. (2019). Ilmu Tajwid Lengkap (Revisi)(Revisi). El-Ameen Publisher. Jakarta. https://books.google.co.id/books?id=6Af9DwAAQBAJ

Andhini, N. F. (2013). Tinjauan Hukum Pendirian Badan Hukum Koperasi Meidya Anugrah. Journal of Chemical Information and Modeling, 1(9), 1689-1699. https://doi.org/D 10107388

Azhar Arsyad, M. A. (2002). Media Pembelajaran (1st ed.). Raja Grafindo Persada. https://doi.org/10.31227/osf.io/34rhg

Budiyanti, E. (2020). Dampak Virus Corona Terhadap Sektor Perdagangan Dan Pariwisata Indonesia. Kajian Bidang Ekonomi Dan Kebijakan Publik, XII(4), 19-24. Singkat-XII-4-II-P3DI-Februari-2020219.pdf

Chaniago, S. A. (2015). Pemberdayaan Zakat Dalam Mengentaskan Kemiskinan. Jurnal Hukum Islam, 13(1), 47. https://doi.org/10.28918/jhi.v13i1.495

Fahham, A. M. (2011). Paradigma Baru Pengelolaan Zakat di Indonesia. Paradigma Baru Pengelolaan Zakat di Indonesia.Pdfat, 3(19), 9-12.

Hendrik Pandu Aksi. Lita Ariyanti (Ed.). (2020). Sekolah Dalam Jaringan. Scopindo Media Pustaka.

Kamaruzaman. (2020). Persepsi Mahasiswa Non-Bisnis Terhadap Kuliah Kewirausahaan Pasca Pelatihan Penyusunan Bisnis Plan. Jurnal Ekonomi Islam AL-AMWAL, 9(1), 28-37. http://jurnal.stei-iqraannisa.ac.id/index.php/al-amwal/article/view/144

Laily Amin Fajariyah. (2018). Pembelajaran Teks Report Dengan Proyek "Cerdig" Berbasis Kinemaster. Jurnal Dikdaktika Pendidikan Dasar, 2(1). https://doi.org/lailyamin@ gmail.com

Mustaqim, I., \& Prianto, E. (2015). Modul Pelatihan Media Pembelajaran Microsoft Powerpoint. p.1-17.

Nasrizal., S. (2005). Peran Notaris Sebagai Pembuat Akta Koperasi Di Kabupaten Kebumen. Universitas Diponegoro Semarang.

P3M STAIN. (2020). Metode KKN Participatory Action Research. STAIN Sultan Abdurrahman.

Perwako Tanjungpinang No. 29. (2020). Perwako Tanjung Pinang No. 29 Tahun 2020 (p. 21). Wali kota Tanjungpinang.

Rakhmawati Purba, Aisyah Siregar, Rumiris Siahan, Suci Etri Jayanti S., R. (2020). Pembelajaran Berbasis Google Classcroom, Google Meet Dan Zoom Guru SMP Negeri 2 Batu Bara. BERNAS: Jurnal Pengabdian Kepada Masyarakat, 1(4), 410-416. https://doi.org/10.31949/jb.v1i4.464

Ratangin, M. G. (2017). Pergeseran Kekuatan Hukum Akta Pendirian Koperasi Serta Kewenangan Notaris Sebagai Pejabat Pembuat Akta Koperasi. Universitas Islam Indonesia.

Shaleh, M. (2001). Pendistribusian Zakat Bagi Mustahik (Ketiga). Gema Insani.

Team eLearning UIN Malang. (2020). Panduan Teleconference menggunakan Google Meet Bagi Presenter

(Dosen). In Panduan (p. 5). UIN Maulana Malik Ibrahim. https://doi.org/elearning@uinmalang.ac.id UIN

Tim P3M STAIN. (2020). Pelaksanaan KKN Covid-19 menggunakan pendekatan ABCD. STAIN Sultan Abdurrahman. 